of complex psychological mechanisms enabling individuals better to practise and detect cheating, including elaborate moral codes and the unconscious. Similarly, kin selection may have promoted the evolution of a basic psychological mechanism of identification; and once in place, this may have permitted the development of anything and everything from masochism to heroic self-sacrifice on the field of battle.

The strength of this freudian-darwinian approach to human behavour lies in its recognition of the need for a cogent psychological theory to place between the abstract principles of biology, on the one hand, and the concrete realities of human society, on the other. Its weakness, however, lies in the sloppiness of the theoretical constructs that lie at the heart of darwinized psychoanalysis. Take, for example, the central notion of identification. Supposedly, our ancestors evolved a basic ability to identify with close kin in order that they should aid them in circumstances that would promote their own inclusive fitness. Well and good; but for such an ability to evolve, it is necessary that it should be highly discriminating; for much (indeed, most) helping behaviour is detrimental to inclusive fitness and could never evolve. What we need to know, then, is what kind of identification mechanism is being proposed. This we never learn. Instead, we are presented with an allegedly evolved geneticpsychological trait which is so indiscriminate that it leads people to behave altruistically towards virtually anyone and everyone. Under what circumstances could such a dangerous trait as this possibly evolve?

Psychoanalytic theory has always suffered from the problem that its central claims are insufficiently specified to permit the formulation of scientifically testable predictions. Recently, a certain genre of sociobiological literature has rediscovered the superficial appeal of equally vaguely-formulated hypotheses about the roots of human conduct. Having set out to combine the two enterprises, it is perhaps not surprising that Badcock has fallen victim to the trap of explaining both too little and too much. This is a pity, for the ideal of a powerful and a predictive evolutionary psychology is a worthy one. We know that Darwin's basic insights can be applied rigorously to behaviour in general. Perhaps at least some of Freud's ideas could be re-cast in such a way that they, too, could be applied rigorously to human conduct; but this has yet to be shown. In the meantime it has to be said that no genuine "freudian-darwinian solutions" are to hand.

John R. Durant is Staff Tutor in Biological Sciences in the Department for External Studies, University of Oxford, Rewley House, 1 Wellington Square, Oxford OXI $2 J A, U K$.

\section{Scrotum hokum}

\section{Walter Gratzer}

The Monkey Gland Affair. By David Hamilton. Chatto \& Windus, London: 1986. Pp.155. £11.95.

According to Dr Johnson, a life protracted is protracted woe. In 1953 the good Pope Pius nevertheless journeyed to Switzerland to receive injections of testicular tissue at the hands of the egregious Dr Niehans. His bid for rejuvenation (though presumably not virility, by which it was generally measured) must have been accounted successful, for shortly afterwards the Mephistopheles in this Faustian contract was elevated to membership of the Pontifical Academy. This occurred two years after Serge Voronoff, in his day the most celebrated and successful exponent of testicle (or, as the euphemism of the time had it, monkey gland) implants, had died, discredited, despised and mocked by the society that had lionized him for two decades. Science does not eradicate human credulity, it merely shifts its focus.

The search for the secret of eternal youth has attracted not only crackpots and mountebanks, but also serious and sometimes even distinguished scientists, whose reason could be selectively suspended. The most illustrious of these was Metchnikoff, who was convinced that aging was caused by bacteria in the gut, which destroyed connective tissue. These, he held, could be driven out by abundant ingestion of yoghourt. Examples nearer to our own time include the view that antioxidants can arrest the processes of decline through the elimination of free radicals, and that lead clothing to exclude cosmic radiation will encompass the same end. None of these theories ever achieved much of a popular following; yet in the 1920s one fancies, there must have been queues of rich, aging voluptuaries in the ante-rooms of "Doc" Brinkley's clinic in Kansas and at the Vienna "Vivarium", their trousers draped over their arms, braces dangling, impatiently awaiting their goat testis implants or unilateral vasectomies - which the learned Professor Steinach was able to assure them would result in the retention of sperm in the testis and thus suffusion of the system with youth and vitality. (This is curiously reminiscent of the principle upheld by the yogis, that the emission of sperm, which they equate with manly virtue, enfeebles the body, so that one must learn to aspirate it back after coition. Many Victorian moralists subscribed to the same opinions, but prescribed abstinence as a corrective.) Steinach treated women by the even less appealing method of $\mathrm{X}$-irradiation of the ovaries.

David Hamilton, who is both a surgeon and a historian of medicine, has written a scholarly, absorbing and vivid account of the history of testicular implantation, which thrived in the first half of this century. For Hamilton, the most interesting figure amongst the galère of improbable characters that throng his pages is Voronoff, because he was sincere in his efforts, deluded rather than a charlatan, and within limits rational in his beliefs.

These limits were set by an unfathomed though common ignorance, verging on obscurantism, about the techniques of experimental design and evaluation. The same attitudes of mind are still with us, and they animate homeopathy, psychoanalysis and a range of other peripheral disciplines. The reasoning behind implantation therapy was not new, and amounted to little more than that the testis was the seat of fertility, therefore of youth. However the discovery of endocrine secretions encouraged the plausible hope that foreign testicular tissue might be the source of some benign active princi-

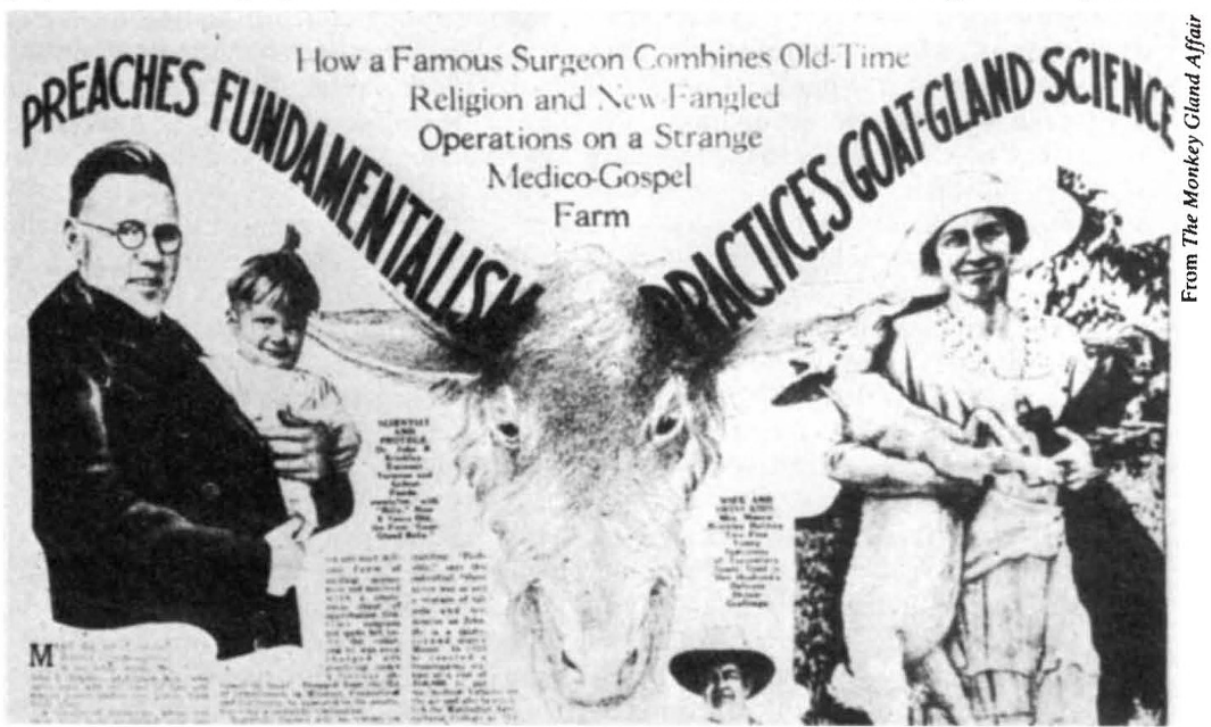

The Kansas quack - a feature about "Doc" Brinkley in the New York Evening Journal. Brinkley is shown holding the first "goat gland baby", born to one of the recipients of a goat testis implant. 
ple. Voronoff became persuaded that a successful xenograft must in general come from a closely related species, not for example from ruminants, and many monkeys were emasculated in the interests of this theory. In the United States prison doctors joined in the game, and were able to go one better: Dr Stanley of San Quentin gaol implanted 30 of his charges with testicles from executed felons and later reported highly satisfactory results from 643 assorted gland transplant operations. All these grafts must of course have been rapidly rejected.

Worse yet was Brinkley, the Kansas quack - unencumbered by any genuine medical qualifications. He chose the goat (an odourless variety), as a species traditionally associated with sexual exuberance, to turn the prematurely enfeebled into satyrs. He and his wife introduced what amounted to a conveyer-belt system of surgery. As a decorative touch, he even injected mercurochrome into the severed end of the vas deferens, to impart a rich colour to the urine and impress the patient. Brinkley owned the hotels that served as convalescent centres, and he set up a radio station to advertise his operation (which was offered in standard and de luxe versions), as well as a range of pharmaceutical products. He became extremely rich and popular, and fought a close-run election for State Governor before his luck ran out.

Meanwhile in Paris, Voronoff had married into money on a grand scale and had become a social lion. His second marriage was to a surmised daughter of King Carol of Roumania and the infamous Madame Lupescu. Hamilton makes the point that in the aftermath of the Great War, in which the best had perished and the breeding stock of the upper classes been seriously depleted, and when indeed eugenic theories were widely touted, European society was peculiarly receptive to promises of increased virility and fertility. Voronoff, who was a tireless and prodigiously talented self-publicist, took full advantage of these preoccupations. $\mathrm{He}$ also extended his activities to the breeding of sheep, in which he saw great pecuniary promise. The results of Lamarckian (or Lysenkoist) experiments, conducted in Algeria, on the effects of testicular grafts on the performance of rams and the woolyield of their offspring, were proclaimed a triumph; the British Thoroughbred Breeders Association took fright and announced that grafted racehorses would be struck from the stud-book.

Then Voronoff fell like Lucifer. He was brought down largely through the resolute scepticism of a number of French and English vets, who knew an uncontrolled experiment when they saw one - a circumstance shaming to the medical establishment, which had vacillated feebly throughout Voronoff's years of ascenden- cy. The most tenacious and clear-sighted was Henri Velu, who ran a sheepbreeding station in Morocco, and in the end he outfaced Voronoff and his many powerful supporters. Moreover testosterone had shortly before been isolated by (as Hamilton calls him) a Dr Funk. This was none other than Casimir Funk, the man who gave us the word vitamin and was said to have enraged the Mussolini regime when, learning that Italian prisoners taken in the Abyssinian War were being castrated by their captors, he attempted to negotiate a consignment of the resulting material. Injections of testosterone were found ineffective in the treatment of sexual decline. So began Voronoff's years of eclipse.

David Hamilton has penetrated the shell of Voronoff's formidable public persona, and come to like the man within, self-seeking poseur though he quite evidently was. Tout comprendre, as they say, est tout pardonner. The book is dedicated to Serge-Samuel Voronoff.

Walter Gratzer is in the Medical Research Coun cil Cell Biophysics Unit, Kings College London (KQC), 26-29 Drury Lane, London WC2B $5 R L, U K$.

\section{Medical matters}

\section{Lewis Thomas}

The Oxford Companion to Medicine, Vols I and II. Edited by John Walton, Paul B. Beeson and Ronald Bodley Scott. Oxford University Press: 1986. Pp.1,524. £55, \$95.

I PICKED up the first of these two volumes at 11 o'clock one evening, and could not lay it down until 11:05. This sounds like the start of an uncordial review, but it means only to say quickly that this new encyclopaedia is not made for steady latenight reading. But for leafing through at random, in spare moments, with nothing particular in mind, The Oxford Companion to Medicine contains some unexpected pleasures. All in all, it is an earnest but good-natured piece of work, 1,500 or so pages of what seem rather randomly selected topics, some of them just a few lines of definition, others lengthy essays on one or another aspect of medicine, health, disease, medical practice, and quite a lot on the organization and economics of medicine.

Among the surprises, for me anyway, is a long essay on Doctors as Patients ("doctors have a healthy skepticism about the efficacy of the art they practice"), Doctors as Athletes, Doctors as Missionaries, Doctors in Other Walks of Life (the arts, the law, philosophy, the Church, crime).

Although the editors state in their preface that they hope for a readership made up of intelligent laymen as well as physi- cians, nurses and other health care professionals, including students, my guess is that the volumes will be most appealing to people who simply like browsing, whatever their background. If, as the editors hope, there is "a plastic surgeon wishing to learn more about the role and responsibilities of a psychiatrist", he will find plenty to read, eleven pages on Psychiatry and another ten on Psychology in Relation to Medicine. The psychiatrist, for his part, will find five pages on Plastic and Maxillofacial Surgery, directly following a short paragraph explaining Plaster of Paris. And any practitioner or layman wanting to know more about Death, Dying and the Hospice Movement, or about Government and Medicine in the UK (and also in the USA), or about Community Medicine, or Dentistry, or Cardiothoracic Surgery, or Medical Museums, or the Medical Services of the Royal Navy, or Women in Medicine, will find pages of essays on these and other broad topics. But, along the way, the casual reader will run into the Opening Snap ("associated with mitral valve opening at the beginning of diastole"), Suffocation ("the interruption of breathing by deprivation of air"), Weakness ("lack of strength, feebleness, ill health"), Neurotoxin ("any agent which is toxic to nervous tissue") and a lot of other items not needing even the one or two lines given them.

Whatever the intended readership, one thing The Oxford Companion to Medicine is not: it is not, despite the title, any kind of guide for do-it-yourself-at-home medicine, and the lay person who shells out $£ 55$ with this in mind will be disappointed. There is, to my own disappointment, not even much material to enlighten the layman on what to stay away from, in the light of those endless shelves of paperbacks in every airport lounge providing promises by immunity-stimulating diets, magical exercises, trace metals, vitamins, rejuvenating lotions, even books on how to think straight. To be sure, if you go looking you can find some of this, under Fringe Medicine, Cults and Quackery. In the absence of an index (which these two volumes could surely use) you have to be lucky and browsing through the F's to find it, and even so this section deals mostly with the health frauds of the nineteenth century and not enough with the more outrageous follies of this one.

In short, this is a curious, rather unpredictable, almost quirky encyclopaedia. Some will find it useful in spots, interesting for some of the essays. I'm glad to possess it, but I'm afraid that long before my pages became thumbworn my thumbs would be pageworn.

Lewis Thomas is Professor Emeritus at the Memorial Sloan-Kettering Cancer Center, 1275 York Avenue, New York, New York 10021, USA, and University Professor at the State University of New York, Stony Brook. 